Review Article

\section{The Importance of Potato virus $Y$ Potyvirus}

\author{
Mahmoud Hamdy Abd El-Aziz* \\ Plant Pathology Institute, Agricultural Research Center, Alexandria, Egypt
}

\section{Abstract}

Potato virus $Y$ potyvirus (PVY) is one of the most important aphid transmitted viral pathogen of potato worldwide. PVY affects potato plant (Solanum tuberosum L.), which is an important economic crop. PVY infection with potato viruses usually causing severe economic damage affecting both tubers quality and trade. PVY can degrease the production of certified seed and also crops grown for processing or fresh market. Potato is considered as one of the most economically important solanaceous crops cultivated in different regions that (PVY) has been studied in many parts of the world. Wide host plant range is a characteristic of viruses belonging to the Potyviridae. 495 species in 72 genera of 31 families were reported to be infected by PVY. Under field conditions, potato plants are subjected to attack by many viruses. The most cited virus could affect potato in the world is PVY. It has been long recognized as a threat to potato cultivation. Several studies carried out and reported that PVY is the most important virus infecting potato in different localities. Our review article is showed that PVY are the most frequently detected viruses in potato.

\section{More Information}

*Address for Correspondence: Mahmoud Hamdy Abd El-Aziz, Plant Pathology Institute, Agricultural. Research Center, Alexandria, Egypt, Email: maziz70@yahoo.com

Submitted: 10 February 2020

Approved: 18 February 2020

Published: 19 February 2020

How to cite this article: Abd El-Aziz MH. The Importance of Potato virus Y Potyvirus. J Plant Sci Phytopathol. 2020; 4: 009-015.

DOI: dx.doi.org/10.29328/journal.jpsp.1001044

Copyright: @ 2020 Abd El-Aziz MH. This is an open access article distributed under the Creative Commons Attribution License, which permits unrestricted use, distribution, and reproduction in any medium, provided the original work is properly cited.

Check for updates

OP OPEN ACCESS

\section{Introduction}

Potato virus $Y$ Potyvirus (PVY) was described for the first time in the early 1930s as the causal agent of a serious disease in potato [1]. PVY has been studied in many parts of the world [2]. PVY is still major virus of potatoes because it spreads easily and depresses yield so much. It is one of the most important aphid transmitted (non persistent manner) viral pathogen of potato worldwide [3]. Depressing varies with cultivar and strain $[4,5]$. PVY is one of the most important aphid transmitted viral pathogen of potato worldwide. It can affect the production of certified seed and also crops grown for processing or fresh market (Rykbost, et al. 1999). The virions of the viruses belonging to the Potyvirus genus are rod-shaped flexuous filaments $680-900 \mathrm{~nm}$ long and $11-13 \mathrm{~nm}$ wide [6]. Molecular genome characterization has identified where recombination events on PVY genomes have occurred to create new strains such as PVY ${ }^{\mathrm{N}-\mathrm{W} i g a}$ and $\mathrm{PVY}^{\mathrm{NTN}}$ [7].

\section{Classification and electron microscopy}

PVY was described for the first time in the early 1930s as the causal agent of a serious disease in potato [1]. PVY is the type member species of the genus Potyvirus, family Potyviridae. PVY has a long filamentous particle containing a single stranded, positive sense RNA genome of approximately 9.7kb [8]. Transmission electron microscope examination of partially purified preparation from infected Nicotiana glutinosa leaves negatively stained with phosphotungistic acid revealed the rod flexible (helical symmetry) particles of PVY with $730 \mathrm{~nm}$ (Figure 2) [6]. PVY infects solanaceous plants such as tobacco, tomato, pepper and potato and has a significant impact on potato and other solanaceous plants [9]. PVY has been studied in many parts of the world. It is still major virus of potatoes because it spreads easily and depresses yield so much (up to $80 \%$ ). Depressing varies with cultivar and strain $[4,5]$. The potato $(S$. tuberosum L.) is an important economic crop, however, its infection with potato viruses usually causing severe economic damage affecting both seed quality and trade (Figure 1a) [10]. PVY is one of the most important aphid transmitted viral pathogen of potato worldwide. It can affect the production of certified seed and also crops grown for processing or fresh market (Rykbost, et al. 1999). In Egypt, PVY is widely spread and isolated from potato plants $[4,11,12]$. PVY was isolated from different crops such as potato, tomato, gladiolus and pepper $[13,14]$. Also, isolated three isolates of PVY from naturally infected potato plants cvs. Nicola and Diamont at different farms [15].

Approximately 2000 subunits of a single coat protein are organized around the viral genomic RNA in a helical arrangement [16]. Sharma, et al. [17], reported that small drops of purified virus were placed on carbon-coated grids for one minute and dried, then the virus particles existed on grids were stained using 2\% uranyl acetate and dried (Figure 2) [6]. The modal length of particles were determined from 
crude preparation deposited on carbon-formvar coated $38 \mu \mathrm{m}$ (400 mesh) grids negatively stained with $2 \%$ uranyl acetate for one minute and dried, then examined using transmission electron microscope [18].

\section{Symptomatology and host range of Potato virus Y Potyvirus}

PVY infects a number of plant species in the family Solanaceae and causes a wide range of symptoms from symptomless to mosaic, mottling, lesions, stunting, necrosis and plant death, depending on the plant species, the cultivar, the virus strain and isolate [16]. Mustafa, et al. [19], showed that pepper isolate of PVY caused vein clearing and mosaic symptoms on Datura metel (Figure 1b) and Capsicum annum, mosaic on $N$. glutinosa (Figure 1c) and $N$. repanda (Figure 1d) as [6] N. tabacum cv. White Barley, N. tabacum cv. Samsun and $N$. rustica but didn't show any symptoms on Physalis floridana, Chenopodium amaranticolor, C. quinoa and Solanum tuberosum. Datura stramonium is not infectable by PVY [20]. Reaction of potato and other different susceptible plants to PVY was found to be varied from local lesions to systemic symptoms [21], depending on inoculated host, virus strain and environmental conditions [22]. Typical foliar symptoms can include veinal necrosis, leaf drop and a mosaic pattern sometimes accompanied by leaf roughness [23]. Smith [24],

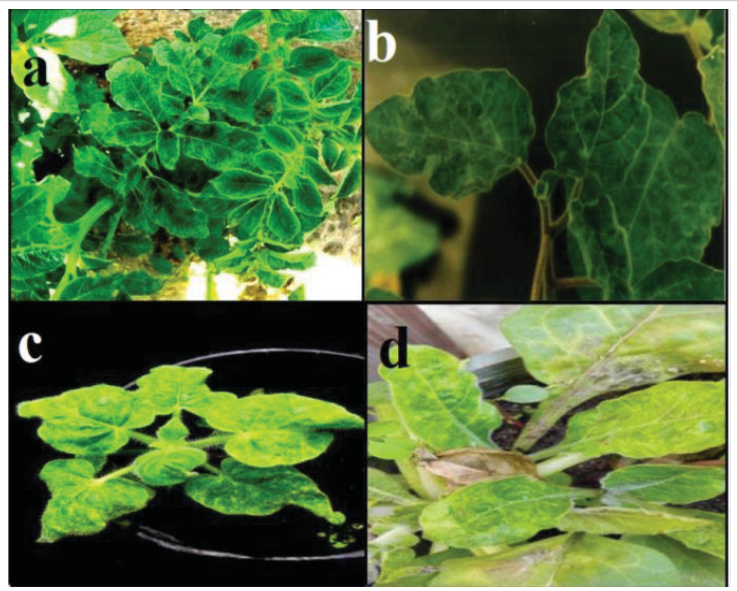

Figure 1: a) Mosaic symptom on potato plants naturally infected with PVY; b) Malformation, blisters and mosaic on D. metal caused by PVY; c) PVY induced mosaic symptoms on $N$. glutinosa; d) Mottling symptoms and yellow leaves appears on $N$. repanda after mechanical inoculation.

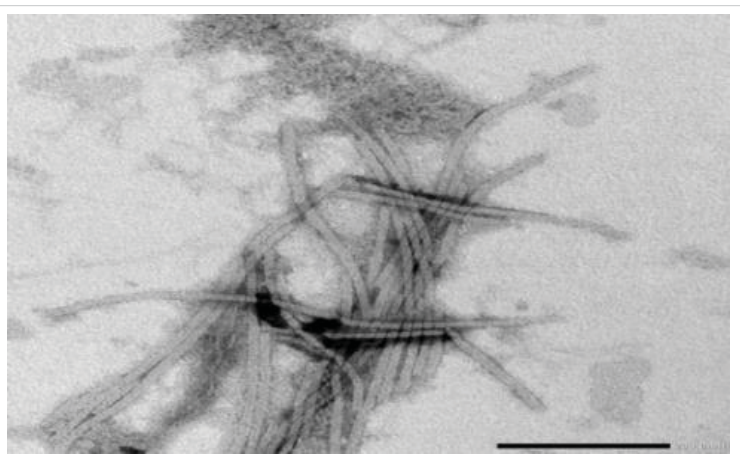

Figure 2: Electron micrograph showing rod flexible particles (helical symmetry) of PVY isolate negatively stained with $2 \%$ phosphotungistic acid with magnification power $40000 x$. described the differences in disease reaction by number of different potato cultivars. Different patterns of symptoms of PVY infection were recorded by several authors [25,26]. Rich [21], concluded that chronic symptoms on potato plants consist of chlorotic mottling, severe rugose wrinkling, moderate to severe dwarfing and premature death. Tubers are smaller than normal. Current-season symptoms are characterized by the development of brown necrotic streaks along the veins of the leaves, the petioles, and the stems. In severe cases, the leaves and petioles die and hang downward from the stems; hence the name "leaf drop streak" was adopted. Severity of symptoms expression varies considerably from one cultivar to another. If infection takes place later in the season, tubers may become infected without development of plant symptoms [27,28]. Eskarous, et al. [29], reported that PVY caused mottling, vein clearing and leaf abnormalities on $S$. nigrum var. judaicum. The virus induced systemic symptoms with vein clearing and vein banding, in $N$. tabacum [21]. In this respect, Park, et al. [30] observed that the virus caused vein banding and necrosis on Burley tobacco plants. Vein clearing, vein necrosis and bronzing were observed on three tobacco cultivars, namely virgin A Mutant; Virginia Aurae and Virginia. These cultivars were previously reported as being immune to PVYN [31]. Some workers found that C. annum was not susceptible to PVY [4], but other workers stated that extremely severe leaf necrosis followed by leaf drop, occurred in very young chill seedlings, while older plants were only mildly affected by vein banding and mosaic disease [32,33]. El-Hammady, et al. [34], studied the susceptibility of 14 pepper cultivars (C. annum) to PVY (Previously isolated from naturally infected pepper plants) and found that all tested cultivars were susceptible but with different degrees. Ch. amaranticolor was recorded as a local lesion host for this virus $[21,34,35]$. Ch. quinoa was also used as a local lesion host for PVY [26,36]. In addition, El-Hammady et al. [34] reported that the virus produced local lesions on Ch. album. The potato hybrid A6 ( $S$. demissum $\times$ S. tuberosum) is the most important indicator host for PVY detection, that the virus produced local lesions accompanied with systemic symptoms on this indicator host [36]. Wide host plant range is a characteristic of viruses belonging to the Potyviridae. 495 species in 72 genera of 31 families were reported to be infected by PVY in the laboratory [37]. PVY has a wide range of natural host species, some of which are edible crops like potato, tobacco, pepper, and tomato, while others are ornamental plants (Dahlia and Petunia spp.) or weeds such as Datura spp., Physalis spp., $S$. dulcamara and $S$. nigrum [38]. It has been reported that the weed S. elaeagnifolium, which is abundant in potato fields in Tunisia and other Mediterranean countries, is infected up to $32 \%$ by PVYN $^{\mathrm{N}}$ which can provide a source for virus infection of potatoes [39]. There are recent reports of such new hosts. For example, Fletcher (2001) reported that Cotula australis and Capsella bursa-pastoris can be infected naturally by PVY. In Europe, Kaliciak and Syller [40], reported other new wild hosts for PVY including Erodium cicutarium, Geranium 
pusillum, Lactuca serriola and Lamium purpureum. Chikh-Ali, et al. [41], reported that PVY is very common in S. nigrum and Physalis spp. which are abundant at the field margins in potato crops in Syria. They speculated that these weeds may serve as a virus source for aphids alighting on potato crops. This growing list of alternative host species is very challenging when designing virus control strategies, particularly because of the important role of these hosts in providing virus sources for aphid vectors, several investigators recorded that PVY can infect many hosts belonging to different families. These families are about eight of the angiosperm [21]. S. tuberosum is the main host of PVY [1,25]. Singh, et al. [42], found that PVY causes diseases and production loss in tobacco crops, pepper (C. annuum L.), tomato (S. Lycopersicum L.) [43] and Ch. Amaranticolor [24,34], D. metel, N. debneyii [22,34,36], N. glutinosa [26,34], N. tabacum [21,26,34,35], S. dulcamora [21], S. melongena [44], S. nigrum [21,25,34] and Petunia spp $[21,34,36]$. D. stramonium was recorded as immune host for PVY infection [4,25,34,35,45,46]. In addition, Gomphrena globosa, Ch. amaranticolor, Ch. quinoa, Ch. Murale and Ch. album were also found to be immune for PVY [4,22,34,45,47].

\section{Transmission of Potato virus Y Potyvirus (PVY)}

PVY is transmitted easily by mechanical inoculations $[4,6,29,45,48-51]$. The virus was found to be stylet-borne in many species of aphids [21]. The green peach aphid (Myzus persicae Sulz.) is the most common and efficient vector $[36,48,52,53]$. Other aphid vectors include Aphis compositae, A. craccivora [29], Rhopalosiphum padi [52,53] and A. nerii [6]. According to [53], M. persicae and Acyrthosiphon pisum were the most effective vectors, infecting $26 \%$ and $25 \%$ of the test plants respectively. A. fabae, A. nasturtii and Rhopalosiphum padi infected only $1 \%-7 \%$ of the test plants. Sitobion avenae and Brevicoryne brassicae did not transmit $\mathrm{PVY}^{\circ}$. The virus is transmissible through infected tubers $[11,21,54]$.

\section{Purification of Potato virus Y Potyvirus}

The methods used in purification of PVY by several investigators were different from each other mainly in the type of extraction buffer and the type of organic solvent used to clarify the leaf extract [55]. Sankari et al. [56], reported that Virus purification was carried out according to [57] with some modifications by [6]. In brief, infected leaves were triturated with four volumes (v/w of leaf tissue) of $0.1 \mathrm{M}$ Citrate buffer (pH 7.2) containing 0.02 M EDTA, 0.04 M Sodium sulfite, $0.2 \%$ mercaptoethanol, and $0.1 \%$ Triton $\mathrm{X}-100$. Then this was mixed with cold chloroform : charbontetrachloride (1:1) to $50 \%$ of total tissue and buffer volume. Mixture was centrifuged at low speed (10000 g) and aqueous phase was stirred with .4\% PEG and $0.4 \mathrm{M} \mathrm{Na} \mathrm{Cl}$ for one hour followed by low speed centrifuge (10000 g). Pellet was dissolved in 0.02 $\mathrm{M}$ Tris- $\mathrm{HCl}$ (pH 7.2) containing $0.1 \%$ mercaptoethanol, $0.01 \mathrm{M}$ EDTA and $0.1 \%$ Triton X100 and mixed with cold chloroform and finally centrifuged at low speed (10000 g). Aqueous phase was centrifuged at high speed (110000 g) and the resultant pellet was dissolved in $0.02 \mathrm{M}$ Tris- $\mathrm{HCl}$, pH 7.2 containing 0.01 M EDTA. Dissolved pellet was layered on (10-40\%) sucrose gradients and recovered virus zone was diluted in 7.2 $\mathrm{M}$ Tris- $\mathrm{H} \mathrm{Cl}$, pH 7.2 containing 0.01 M EDTA and centrifuged at high speed (112000 g) for $90 \mathrm{~min}$. at $4^{\circ} \mathrm{C}$ Purified virus was dissolved in $\mathrm{Na} \mathrm{Cl}(0.85 \%)$ solution and stored at $-80{ }^{\circ} \mathrm{C}$. Nerway and Kassim [58], Modified procedures of $[59,60]$ to purify PVY using differential centrifugation, precipitation and filtration technique.

Spectrometrical tests were used to assess the purity of PVY suspension and the efficiency of procedure used to purify the virus. This test was done using UV-spectrophotometer for scanning the purified solution at a wave length ranged between 200-300 nm, at $10 \mathrm{~nm}$ intervals [58] to plot the absorbency curve, estimate A260/A280 ratio (nucleic acids : nuclei protein) and PVY concentration in potato tissues. The virus yield was calculated according to [61] as follows: Virus yield = O.D. (260) X Dilution factor/ E.C. Whereas: O.D. = optical density at $260 \mathrm{~nm}$; E.C. = extinction coeffcient 2.4 (mg/ $\mathrm{ml}^{-1} \mathrm{~cm}^{-1}$ ).

\section{Polyclonal antiserum production from Potato virus $Y$ Potyvirus}

Nerway and Kassim [58], mentioned that antiserum was produced according to that of [61], as follows. $2 \mathrm{ml}$ of the purified viral preparation was injected intravenously at interval of one week into the ear vein of albino New Zealand male rabbit. After two weeks, the injection was repeated at the same quantity (booster injection) intramuscularly into the muscle of rabbit, after mixing the purified virus solution with sterilized alum solution (1:1). Kassim and Ali, [62], reported that the injected rabbit with PVY was bleed $\mathbf{7}$ days after final injection, $15 \mathrm{ml}$ of the blood was taken from the injected rabbit. The antiserum was obtained and purified as reported by [63]. Blood was allowed to clot at room temperature, and the clot was removed. Clotted blood was centrifuged at 5000 rpm for 10 minutes. The clear antiserum (supernatant) was collected and discarded the pellet. The antiserum (serum plus antibodies) was poured into a small vial and kept frozen at $-18^{\circ} \mathrm{C}[6,58]$.

\section{Serological detections}

Serological techniques are useful and accurate test for identifying PVY [64]. ELISA was the most common serological test used to diagnose viral diseases in potato $[5,50,65]$. Lin, et al. [66], described a technique of tissue-blot immunoassay (TBIA) on nitrocellulose membranes for detection of plant viruses and micoplasma-like organisms (MLO) in infected plants. Tissue blots were made by pressing, with a firm and gentle force, the freshly cut tissue surface on nitrocellulose membranes. The reliability of ELISA when used on leaves is efficient and reliable as using nucleic acid based technique [67]. In certification programs, it is the most practical diagnostic method which is performed using leaf sap for routine testing 
of large number of potato plants [68]. Testing of potato tubers using ELISA has not been shown to be accurate and reliable [47,69-71]. Antigens in tissue blots on nitrocellulose membranes were detected by enzyme-labeled immunological probs [66]. Indirect immunological methods, the blots were reacted with antigen-specific primary antibodies and detected with enzyme-labeled species-specific secondary antibodies [2]. Alternatively, the blots were reacted with antigenspecific biotinylated primary antibodies and detected with avidin-enzyme conjugates. Indirect immunological methods, the blots were reacted and detected with enzyme-labeled antigen-specific antibodies [66]. Samson, et al. [72] pointed out that serological detection of potato viruses was more sensitive, faster and less expensive with direct tissue blotting (DTBA) than with ELISA. Positive reaction were obtained with Tobacco rattle Tobravirus (TRV), Potato virus $S$ Carlavirus (PVS), PVY, Potato virus $M$ Carlavirus (PVM), Potato virus $A$ Potyvirus (PVA), Potato virus $X$ Potexvirus (PVX) and Potato leaf roll Luteovirus (PLRV). Viruses were detected in leaves, petioles, stems, roots and tubers [73].

\section{Molecular detection of Potato Virus Y Potyvirus by reverse transcription polymerase chain reaction (RT-PCR)}

In 1989, scientists selected polymerase chain reaction as the major scientific development of the year [74]. Nowadays RT-PCR is considered to be the most powerful tool in molecular biology. In the past, serology was routinely used for the detection of plant viruses from infected tissues. However, this method is less sensitive than some other techniques such as nucleic acid hybridization or PCR, which are becoming more popular [75]. PVY is a rapidly evolving virus [10], where both variation within strains and recombination events between strains occurs. Analysis of the genome using molecular biology methods has brought a new understanding of PVY at a nucleotidic level. Rapid developments in molecular biology and sequencing of isolates since the late 1980s have made it possible to characterise and classify PVY strains based on molecular characteristics [76-78] which may or may not correspond to traditional PVY strain groups. Overall, at the nucleotidic level, multiple isolates of the PVY ${ }^{0}$ and $\mathrm{PVY}^{\mathrm{N}}$ groups differ from each other by approximately 8\% along their genomes [79]. Molecular genome characterization has identified where recombination events on PVY genomes have occurred to create new strains such as PVYN-Wilga and PVYNTN [7]. Molecular characterisation has also revealed that in many countries the majority of isolates are now recombinants between $\mathrm{PVY}^{0}$ and $\mathrm{PVY}^{\mathrm{N}}[80,81]$. Takacs [82], studied the main characteristics and diagnostic methods of PVY and its strains, $\mathrm{PVY}^{\mathrm{O}}$ (normal strain), $\mathrm{PVY}^{\mathrm{C}}$ (strain C), $\mathrm{PVY}^{\mathrm{An}}$ (anomalous strain), $\mathrm{PVY}^{\mathrm{N}}$ (tobacco vein necrosis strain), and PVY $^{\text {NTN }}$ (Potato ring spot strain) were identified using PCR techniques. Several authors used RT-PCR for the detection of PVY and other viruses. The application of PCR for potato viruses detection has already been reported [83]. This method followed by an additional restriction enzyme digestion of the amplification product has potential for rapid identification of PVY isolates [84]. Rapid molecular methods have recently been developed for virus strain differentiation, based on restriction fragment length polymorphism (RFLP) [84] and single-stranded conformation polymorphism (SSCP) [85] of PCR products. The RT-PCR is used to characterize isolates of potato viruses by converting RNA into cDNA followed by amplification and sequencing [86] and Chikh Ali, et al. 2014). RT-PCR method has been also successfully utilized for the detection of PVY in potato tubers [87]. The RT-PCR method has been successfully utilized to detect viruses from infected potato leaves $[2,88]$. Sequencing techniques have enabled molecular taxonomy in closely related species. Using the amino acid sequences of the CP of virus species, the genus Potyvirus exhibit 38\% - 71\% similarity, while strains share $90-99 \%$ similarity [8]. The polymerase chain reaction PCR technology has become the most powerful tool for plant pathologists. Since the adaptation of ELISA to plant virology by [63]. The first published account of PCR in 1985 was its application to the prenatal diagnosis of Sickle cell anemia [89]. PCR is an in vitro method in which by DNA sequences or transcripts are amplified rapidly with very high specificity and fidelity using oligonucleotide primers and Taq DNA polymerase in simple automated reaction. The PCR was developed to use it in the areas of disease diagnosis, detection of pathogens, detection of DNA in small samples, DNA comparison, high efficiency cloning of genomic sequences and gene sequencing. PCR is a powerful technique used for the amplification of a specific DNA sequences and is capable of enrichment by factor of $10^{6}$ to $10^{7}$, enabling the detection of a few target nucleotides [89]. Several investigations in their research work used specific method for extraction of total nucleic acid (TNA) from plant tissue; this procedure was used successfully for the extraction of numerous samples for RT - PCR detection and diagnosis of several viroids and viruses. RT-PCR amplification has been successfully utilized for the detection of RNA plant viruses from infected tissue. Several researches used this technique to detect $\mathrm{CMV}$ in infected samples. Proper virus identification is always the key in developing appropriate practical solutions to manage plant virus diseases $[10,90]$. Recent advances in biotechnology and molecular biology have played a significant role in the development of rapid, specific and sensitive diagnostic tests. Reverse transcriptase PCR (RT-PCR) can be used for viral disease diagnosis because it is a quick and more reliable method in comparison to ELISA, and PCR can be used for further characterization of cowpea plant viruses. Combining PCR with molecular hybridization can detect even pictogram qualities of virus, and this combination is 4 - 5 orders magnitudes superior to direct molecular hybridization (Vunsh et al., 1999). Diagnostic approaches based on nucleic acid hybridization are not only highly specific but also applicable for routine testing of large number of samples. The development of nucleic acid-based tools was another new dimension of virus detection. The most common among these techniques are cDNA hybridization and 
polymerase chain reaction (PCR). In addition, PCR can be used as a confirmatory test for TBIA, where processed blots can be cut individually and tested by PCR. This proved to work well with both DNA and RNA plant viruses. Furthermore, unprocessed plant tissue blots on nitrocellulose membrane represent a good sample for PCR amplification. PCR products can also be used for cloning and subsequent sequencing which is extremely useful for identification of new viruses or virus strains. Gibbs and Mackenzie [91], mentioned that the sequence analysis was used to design a pair of degenerate oligonucleotide primers that amplified a 1.6-2.1 kbp fragment from the 3' end of the genome (virion protein gene and part of the Nib gene) of 17 species of the Potyviridae ('potyvirids'); 11 potyviruses, 2 bymoviruses, 2 macluraviruses, an ipomovirus and a rymovirus. The 'potyvirid primer 1 ' hybridizes to the 3 ' terminal poly-A region of the genome, and 'potyvirid primer 2 ' to the genomic region encoding the-GNNSGQ-motil' of the Nib protein. Database searches showed that the potyvirid 2 primer is specific for potyvirids. Associated analyses indicated that the published amino acid sequence of part of the wheat streak mosaic rymovirus Nib protein is probably incorrect in part. Kumari [92], mentioned the A one-step reverse transcription-polymerase chain reaction (RT-PCR) protocol was developed and used for the detection of Cherry leaf roll virus (CLRV) and Strawberry latent ring spot virus (SLRSV). The protocol was used to test infected screen house plants. The one-step RT-PCR protocol is rapid and sensitive and has the potential to be used for the diagnosis of CLRV and SLRSV in routine diagnostic laboratories [2,92].

\section{References}

1. Smith KM. Composite nature of certain potato viruses of the mosaic group. Nature. 1931; 127: 702.

2. Abd El-Aziz MH, Behiry SI, Younes HA, Hamza KA. The relationship and relativity between three isolates of Potato virus $Y$ Potyvirus infecting potato (Solanum tuberosum L.) at Alexandria and El-Beheira governorates in northern Egypt. Novel Research in Microbiol J. 2019; 3 : 440-452.

3. Abdel-Shafi S, Ghaly M, El-dougdoug K, Taha M. Physiological and Infectious Characters of Potato virus Y-Egyptian isolate. Egyptian $\mathrm{J}$ Microbiol. 2017; 52: 141-155.

4. Allam EK, Omar RA, Kishtah AA. A strain of potato virus $\mathrm{Y}$ (Tobacco veinal necrosis strain) (TVN) affecting potato in Egypt. Annals Agric Sci Fac Agric. 1973; 18: 91-99.

5. Beemster ABR, de Bokx JA. Survey of properties and symptoms. In: de Bokx JA, Van der Want JPH (eds.). Virus of potatoes and seed-potato production. Pudoc Wageningens. 1987; 84-113

6. Hamza KA, Abd El-Aziz MH, Behiry SI, Younes HA. Isolation and purification of potato virus $\mathrm{y}$ isolate infecting potato (Solanum tuberosum I.) in al-nubaria region. Middle East Journal of Agriculture Research. 2018; 7: 1201-1207.

7. Boonham N, Walsh K, Hims M, Preston S, North J, et al. Biological and sequence comparisons of Potato virus $\mathrm{Y}$ isolates associated with potato tuber necrotic ring spot disease. Plant Pathol. 2002; 51: 117 126.

8. Adams MJ, Antoniw JF, Fauquet CM. Molecular criteria for genus and species discrimination within the family Potyviridae. Arc Virol. 2005; 150: 459-479.

PubMed: https://www.ncbi.nlm.nih.gov/pubmed/15592889

9. Walsh K, North J, Barker I, Boonham N. Detection of different strains of Potato virus $Y$ and their mixed infections using competitive fluorescent RT-PCR. J Virological Methods. 2001; 91: 167-173.

PubMed: https://www.ncbi.nlm.nih.gov/pubmed/11164498

10. Abd El-Aziz MH, Hamza KA, Younes HA. Serological and Molecular Studies on potato virus y. NOOR Publishing. 2019; 85

11. Omar RA, Tolba MA, Kishtah AA. Strains of potato virus $Y$ (PVY) affecting potato crop in A. R. E. 1st con of the Egypt. Phytopathol Soc Cairo. 1973; 7

12. Mansour A, Haj-Kasem AO, Salem N, Choueiri E, Abou-Jawdah $Y$, et al. Viruses infecting potato. Pages 273-308. In:Virus diseases of important crops in Arab region. Makkouk K, Fegla G, Kaumari S (eds). Dar EL-Nahda EL-Arabia. 2008; 273-308

13. Ahmad AY. Studies on some viral diseases infecting potatoes. Ain Shams University. 2005; 120.

14. Al-Nagar AM. Studies on some plant virus diseases of some vegetable crops. Al-Azhar University. 2007; 165.

15. Mahfouz SA, Allam EK, Afifi AM, El Dougdoug KA. Isolation of different isolates of PVX, PVY and PVS from naturally infected potato plants. The Ninth Conference of Agriculture Development Researches, 2004; 22-24.

16. Shukla DD, Ward CW, Brunt AA. "The Potyviridae". CAB International. 1994; 102.

17. Sharma P, Sahu AK, Verma RK, Mishra R, Gaur R. Biological and molecular characterization of Potato VirusY infecting potato (Solanum tuberosum) in India. Asian Journal of Biological Sciences. 20413; 6: 257-264.

18. Pennazio S, D'Agostino G, Appiano A, Redolfi P. Ultrastructure and histochemistry of the resistant tissue surrounding lesions of tomato bushy stunt virus in Gomphrena globosa leaves. Physiological Plant Pathology. 1978; 13: 165-168.

19. Mustafa S, Mosahebi G, Habibi MK. Potato virus $Y$ isolated from pepper fields in Tehran Province. Commun Agric Appl Biol Sci. 2006; 71: 13351340.

PubMed: https://www.ncbi.nlm.nih.gov/pubmed/17390898

20. Kazinczi G, Horváth J, Takács AP, Gáborjányi R, Béres I. Experimental and natural weed host-virus relations. Commun Agric Appl Biol Sci. 2004; 69: 53-60.

PubMed: https://www.ncbi.nlm.nih.gov/pubmed/15759395

21. Rich AE. Potato Diseases. Academic Press. 1983; Pg no: 238.

22. Horvath J. Studies on strains of potato virus Y. Acta Phytopath. 1966; 1: 333-352.

23. Whitworth JL, Samson RG, Allen TC, Mosley AR. Detection of Potato Leaf roll Virus by visual inspection, direct tissue blotting and ELISA techniques. Amer Potato J. 1993; 70:497-503.

24. Smith KM. Plant virus diseases. 3rd (Ed.) Longman Group Limited. $1972 ; 684$

25. Laird EF, Desjardins PR, Dickson RC. Tobacco etch virus and potato virus $Y$ from pepper in Southern Californis. Plant Dis Reptr. 1964; 48: 772-776.

26. Lockhart BEL, Fischer HU. Serious losses caused by potato virus $Y$ infection in peppers in Morocco. Plant Dis Reptr. 1974; 58: 141-143. 
27. Harrison BD. Potato viruses in Britain. In: Diseases of crop plants (JH Western, ed.). 1971; 123-159.

28. Rich AE. Potato diseases. In: Potatoes production, storing, processing (O. Smith) 2nd ed. Avi Pub Westport. 1977; 506-549.

29. Eskarous JK, Habib HM, Kishtah AA, Ismail MH. A strain of potato virus $\mathrm{Y}$ isolated from Solanum nigrum var. judaicum in Egypt. Phytopatologia Mediterranea. 1983; 22:53-58.

30. Park EK, Kim J, Boo KS. Two new PVY strains isolated from tobacco plant in Korea. Korean J of Plant Protection. 1984; 23: 209-214.

31. Piccirillo P, Piro F. PVY strains on Burlet tobacco in Southern Italy. In Coresta 1986. Symposium, Taormina. 1986; 26-30.

32. Nagai $H$, Smith PG. Reaction of pepper varieties to naturally occurring viruses in California. Plant Dis Reptr. 1968; 52: 928-930.

33. Vasudeva KS. A vein-banding mosaic disease of chillies (Capsicum fructescns L.) Indian J. Microbiol. 1961; 1: 94-99.

34. El-Hammady M, El-Zayat ME, Hasaaniann SH, Kishtah AA, Ibrahim LM Studies on potato virus $Y$ and tobacco mosaic virus on pepper plants with special regard to varietal susceptibility. $8^{\text {th }}$ International Congress. Ain Shams Univ Press. 1983; 26-31.

35. Nelson MR, Wheeler RE. Biological and serological characterization and separation of potyviruses that infect peppers. Phytopathol. 1978; 68: 979-984.

36. El-Said HM, Allam EK, Mazyad HM, Sabik AM. Viruses affecting gladiolus in Egypt. II. The effect of virus infection on the growth of gladiolus. $3^{\text {rd }}$ Conf Microbiol. 1975.

37. Kerlan C. Potato virus Y. C.M.I./A.A.B. Description of Plant Viruses. $2006 ; 414$

38. Jeffries CJ. Potato. FAO/IPGRI technical guidelines for the safe movement of germplasm: Potato No. 19. Food and Agriculture Organization of the United Nations, Rome/International Plant Genetic Resources Institute. 1998.

39. Boukhris-Bouhachem S, Souissi R, Turpeau E, Rouze-Jouan J, Fahem $\mathrm{M}$, et al. Aphid (Hemiptera : Aphidoidea) diversity in Tunisia in relation to seed potato production. Ann de la Societe Entomol de France. 2007; 43: $311-318$

40. Kaliciak A, Syller J. New hosts of potato virus Y (PVY) among common wild plants in Europe. European J of Plant Pathol. 2009; 124:707-713.

41. Chikh-Ali M, Katayama K, Maoka T, Natsuaki, K. Significance of weed hosts for potato virus $Y$ protection in Syria. Bulletin OEPP/EPPO Bulletin. 2008; 38: 226-232.

42. Singh RP, Valkonen JP, Gray SM, Boonham N, Jones RA, Kerlan C, Schubert J. Discussion paper: The naming of Potato virus $Y$ strains infecting potato. Arch Virol. 2008; 153: 1-13.

PubMed: https://www.ncbi.nlm.nih.gov/pubmed/17943395

43. Romero A, Blanco-Urgoiti B, Soto MJ, Fereres A, Ponz F. Characterization of typical pepper isolates of PVY reveals multiple pathotypes within a single genetic strain. Virus Res. 2001; 79: 71-80.

PubMed: https://www.ncbi.nlm.nih.gov/pubmed/11551647

44. Sastry KS. Studies on the identification of mosaic diseases of brinjal Solanum melongens L. Current Science. 1982; 51: 568-569.

45. Sabik AM. Studies on viruses affecting gladiolus in A.R.E. Ain Shams Univ. 1973.

46. Abd El-Aziz MH. Detection of certain plant viruses. Alex. Univ. 2000; 118.

47. De Bokx JA, Maat DZ. Potato leaf roll virus; antiserum preparation and detection in potato leaves and sprouts with the enzyme linked immunosorbent assay (ELISA). Neth J of plant path. 1978; 84: 149-156.

48. Nakhla MK, El-Hammady M, Mazyad HM. Isolation and identification of some viruses naturally infecting tomato plants in Egypt. $4^{\text {th }}$ Conf Pest Control. 1978; 1042-1051

49. Kamenfkova I. Effectiveness of various inoculation techniques in potato with strains YN of potato virus Y. Sbornik UVTIZ, Genetika a Slechtent. 1987; 23: 141-146.

50. Singh RP, Santos-Rojas J. Detection of potato virus $Y$ in primarily infected mature plants by ELISA, indicator hosts visual indexing. Canadian Plant Disease Survey. 1983; 63: 39-44.

51. Fegla GI, El-Samra IA, Younes HA, Abd El-Aziz MH. Comparative studies for detection of Tomato mosaic tobamovirus (ToMV), Cucumber mosaic cucumovirus (CMV) and Potato Y potyviruses (PVY). Adv Agric Res. 2001 ; 6: 239-254.

52. Katis N, Gibson RW. Transmission of potato virus $Y$ by cereal aphids. Potato Research. 1984; 28:65-70.

53. Sigvald R. Aphid migration and the importance of some aphid species as vectors of potato virus Yo (PVYo) in Sweden. Potato Research. 1987; 30: 267-283.

54. Rahman MS, Akanda AM. Performance of seed potato produced from sprout cutting, stem cutting and conventional tuber against PVY and PLRV. Bangladesh J Agril Res. 2009; 34: 609-622.

55. Azzam Ol, Makkouk KM. Purification of two potyvirus isolates infecting Phaseolus vulgaris L. in Lebanon. Phytopathologia Mediterranea. 1986; 25: 125-130.

56. Sankari S, Chikh-Ali M, Katayama K, Miki N, Said Omar A, et al. The First Report of Polyclonal Antibody Production of a Syrian Isolate of Potato virus Y. Journal of Agricultural Science. 2007; 52: 109-114.

57. Loebenstein G, Berger PH, Brunt AA, Lawson RH. Virus and viruslike diseases of potatoes and production of seed-potatoes. Kluwer Academic Publishers. 2001; 460 .

58. Nerway ZAA, Kassim NA. Potato Virus Y (PVY) Purification and Antiserum Preparation. Journal of Agriculture and Veterinary Science. 2014; 7: 09-12.

59. Dijkstra J, de Jager CP. Practical plant virology. Springer. 1998; 459.

60. Al-ani RA, Adhab MA, Hamad SAH, Diwan SNH. Tomato yellow leaf curl virus (TYLCV), identification, virus vector relationship, strains characterization and a suggestion for its control with plant extracts in Iraq. African Journal of Agricultural Research. 2011; 6: 5149-5155.

61. Noordam D. Identification of plant viruses, Methods and experiments. Center for Agricultural publishing and Documentation. 1973; 207.

62. Kassim NA, Ali H. Purification of Fig mosaic virus by seradest gel filtration and its control. Iraq J Agric Sci. 2004; 5: 101-105.

63. Clark MF, Adams AN. Characteristics of the Microplate Method of Enzyme-Linked Immunosorbent Assay for the Detection of Plant Viruses. J Gen Virol. 1977; 34: 475-483.

PubMed: https://www.ncbi.nlm.nih.gov/pubmed/323416

64. Ozalp NO. Investigation on the identification of plant virus diseases by serological and precipitation tests in Western Turkey. $\mathrm{J}$ of Turkish Phytopathol. 1971; 1: 27-32.

65. Abd El-Aziz MH. Three modern serological methods to detect plant viruses. Journal of Plant Science and Phytopathology. 2019; 3: 101-106.

66. Lin NS, Hsu YH, Hsu HT. Immunological detection of plant viruses and micoplasma like organism by direct tissue blotting on nitrocellulose membrane. Phytopathology. 1990; 80: 824-828. 
67. Zahn V, Dahle J, Pastrik KH. Validation of ELISA for the detection of potato virus antigen in sap of potato plant leaves. Bulletin OEPP EPPO Bulletin. 2011; 41: 30-38.

68. Casper R. Tools for efficient mass testing in enzyme-linked immunosorbent assay (ELISA). Gesunde Pflanzen. 1979; 31:291-293.

69. Vetten HJ, Ehlers $U$, Paul HL. Detection of potato viruses $Y$ and $A$ in tubers by enzyme linked immunosorbant assay after natural and artificial break of dormancy. Journal of Phytopathology. 1983; 108: 41-53.

70. De Bokx JA, Cuperus C. Detection of potato virus $Y$ in early-harvested potato tubers by CDNA hybridization and three modifications of ELISA. Bulletin OEPP EPPO Bulletin. 1987; 17: 73-79.

71. Huttinga $\mathrm{H}$. Sensitivity of indexing procedures for viruses and viroids. Advances in Botanical Res. 1996; 23: 59-71.

72. Samson RG, Thomas CA, Jonathan LW. Evaluation of direct tissue blotting to detect potato viruses. Amer. Potato J. 1993; 70: 257-265.

73. Aseel DG, Abd El-Aziz MH, Riad SA, Makhlouf A, Fegla Gl, et al Molecular characterization of Potato Leaf Roll Virus (PLRV) Infected Potato Plant in Egypt and Cytopathological Effects on Plant Cell Level. Novel Res Microbiol J. 2019; 3: 453-463.

74. Guyer RL, Koshland DE. The molecule of the year. Science. 1989; 246 1543-1546.

PubMed: https://www.ncbi.nlm.nih.gov/pubmed/2688087

75. Matthews REF. Diagnosis of Plant Virus Diseases. CRC Press. 1993; 359

76. Singh RP. Development of the molecular methods for potato virus and viroid detection and prevention. Genome. 1999; 42: 592-604.

77. Nie $X$, Singh RP. A new approach for the simultaneous differentiation of biological and geographical strains of Potato Virus $Y$ by uniplex and multiplex RT-PCR. Journal of Virological Methods. 2002; 104: 41-54. PubMed: https://www.ncbi.nlm.nih.gov/pubmed/12020791

78. Rupar M, Kogovšek P, Pompe-Novak M, Gutiérrez-Aguirre I, Delaunay A et al. Assessment of SNaPshot and single step RTqPCR methods for discriminating Potato virus Y (PVY) subgroups. J Virological Methods. 2013; 189: 93-100.

79. Karasev AV, Nikolaeva OV, Hu X., Sielaff Z, Whitworth J, et al. Serological properties of ordinary and necrotic isolates of Potato virus $\mathrm{Y}$ : a case study of PVYN misidentification. Am J Potato Res . 2010; 87: 1-9.

80. Yin Z, Chrzanowska M, Michalak K, Zagórska H, Zimnoch-Guzowska
E. Recombinants of PVY strains predominate among isolates from potato crop in Poland. J Plant Protection Res . 2012; 52: 214-219.

81. Blanchard A., Rolland M., Lacroix C, Kerlan C, Jacquot E. Potato virus Y: a century of evolution. Current Topics in Virology. 2008; 7: 21-32.

82. Takacs A. Morphology, genetics and strains of the Potato Y Potyvirus. Novenytermeles. 1999; 48: 199-208.

83. Hataya T, Inoue AK, Shikata E. A PCR-microplate hybridization method for plant virus detection. J Virol Meth. 1994; 46: 223-236.

PubMed: https://www.ncbi.nlm.nih.gov/pubmed/8188816

84. Blanco-Urgoiti B, Dopazo J, Sanchez F, Ponz F. A strain-type clustering of Potato virus $Y$ based on the genetic distance between isolates calculated by RFLP analysis of the amplified coat protein gene. Arch of Virol. 1996; 141: 2425-2442.

85. Rosner A, Spiegel S, Mastenin L, Levy D. The use of S1 nuclease treatment of hybrid PCR products for the differentiation between PVY isolates. Ann Appl Biol . 1998; 132: 107-114.

86. Hsu YC, Yeh TJ, Chang YC. A new combination of RT-PCR and reverse dot blot hybridization for rapid detection and identification of potyviruses. J of Virol Meth. 2005; 128: 54-60.

PubMed: https://www.ncbi.nlm.nih.gov/pubmed/15885811

87. Barker H. Multiple components of the resistance of potatoes to potato leaf roll virus. Ann Appl Biol. 1987; 111: 641-648.

88. Shalaby AA, Nakhla MK, Soliman AM, Mazyad HM., Hadidi A, et al Development of a highly sensitive multiplex reversetrans-criptionpolymerase chain reaction (m-RT-PCR) method for detection of three potato viruses in a single reaction and nested PCR. Arab J Biotech. 2002; 5: 275-286.

89. Saiki RK, Scharf S, Faloona F, Mullis KB, Horn GT, et al. Enzymatic amplification of Beta-globin sequences and restriction site analysis for diagnosis of Sickle cell anemia. Scinence. 1985; 230: 1350-1354. PubMed: https://www.ncbi.nlm.nih.gov/pubmed/2999980

90. Makkouk KM, Kumari SG. Molecular Diagnosis of Plant Viruses. Arab J PI Prot. 2006; 24: 135 - 138.

91. Gibbs A, Mackenzie A. A primer pair for amplifying part of the genome of all potyvirids by RT-PCR. J Virological Methods. 1997; 63: 9-16. PubMed: https://www.ncbi.nlm.nih.gov/pubmed/9015271

92. Kumari S. Detection of Cherry Leaf Roll Virus and Strawberry Latent Ring Spot Virus by One-Step RT-PCR. Plant Protect Sci. 2009; 45: 140-143. 